\title{
Informality and poverty in Ecuador
}

\author{
Carla Canelas
}

Accepted: 30 August 2018/Published online: 19 December 2018

(C) UNU-WIDER 2018

\begin{abstract}
This paper uses national representative data from the Ecuadorian Family Expenditure survey to study the determinants of poverty and informality in the country, taking into account the two-way relationship between these two phenomena. The main contribution of this paper is to present new empirical evidence on this relationship for a developing country where more than $60 \%$ of workers are in the informal sector. The results support the view of a heterogeneous informal market, in which informal work is both a demand-led phenomenon and a voluntary and primarily supply-led form of employment.
\end{abstract}

Keywords Informality - Self-employment .

Poverty $\cdot$ Developing economy $\cdot$ Ecuador

JEL Classification E24 $\cdot$ E26 $\cdot$ I32 $\cdot$ L26

\section{Introduction}

For the vast majority of households in the developing world, labor income accounts for the main, if

\section{Canelas $(\bowtie)$}

Centre d'Economie de la Sorbonne, Université Paris 1, 106 - 112 Boulevard de l'Hôpital, 75013 Paris, France e-mail: carla.canelas@univ-paris1.fr

C. Canelas

Department of Economics, American University of Paris, 147 Rue de Grenelle, 75007 Paris, France not the only, source of income. In 2013, the estimates of the World Development Report from the World Bank (2013) revealed that self-employment and farming represent almost half of the jobs in the developing world. They also revealed that the important decline in poverty rates between 1981 and 2008 was achieved, to a large extent, through jobs. If nonwage employment represents such a large share of total employment in these countries, understanding the links between informal jobs (whether defined on the basis of self-employment, social security coverage or written employment contract) and poverty becomes critical from a policy perspective.

Indeed, labor informality is a common characteristic of developing countries, which are also characterized by high levels of poverty. In this context, it is easy to think that a link between poverty and informal employment exists. In particular, one may think that being poor affects the probability of working informally, but also that having informal employment is a determinant of poverty. The question then becomes whether informality is both a cause and a result of poverty. That is, are informal employment and poverty interrelated? While there is some agreement about this idea in the literature, there is still limited evidence about the interactions between the two phenomena. Most articles on informality or poverty consider this only as a one-way relationship and do not take into account the simultaneous causality that may exist between these two phenomenathus, estimates may be biased. This article adds to the 
limited number of empirical studies that address this problem.

The case of Ecuador is of particular interest since little evidence exists for this country even though its poverty and informality rates are among the highest in Latin America. In Ecuador, the share of employees who do not have social security coverage is the highest among the poorest, at $84 \%$ versus $65 \%$ for the not poor. Also, households headed by informal workers have higher poverty rates $(34 \%)$ than those headed by formal workers $(13 \%) .{ }^{1}$ There is thus a strong association between informality and poverty in the country.

This paper contributes to the literature in several ways. First, it controls for the simultaneity of poverty and informality by using a simultaneous equation model that allows for error correlation across equations. While the methodology is not new in the literature, the article adds to the limited number of studies that address the double causality between the two phenomena. Second, it provides evidence for a country for which no other studies link poverty and informality. Third, it presents the results for both salaried and self-employed workers. These results, so far unavailable in the literature, contribute to a better understanding of the heterogeneity of informal sector employment in a developing country.

The structure of the paper is as follows: Section 2 reviews the literature and the main theories of informality. Section 3 describes the data and presents some descriptive statistics. Section 4 presents the empirical specification, Section 5 the results, and Section 6 the robustness checks. This is followed by a discussion and conclusion in Sections 7 and 8.

\section{Conceptual framework and literature review}

The relationship between informal employment and poverty is a very complex one that is not yet well understood. In the theoretical literature on the informal sector, three contrasting views prevail regarding the origins of informal employment-namely the dualistic labor market approach, the alternative or neoliberal approach, and the structural articulation approach.

In the first approach, informal employment is seen as an involuntary solution to unemployment-it is the second-best strategy that substitutes for the lack

\footnotetext{
${ }^{1}$ Estimates based on the official consumption poverty line, considering informal salaried workers and self-employed together.
}

of formal employment. As such, the informal sector absorbs the surplus labor in the economy. In this view, informal employment is involuntary, requires little capital investment and only provides a subsistence wage. This approach originated with the works of Lewis (1954) and Harris and Todaro (1970), and was later extended by Fields (1975).

The alternative (or neoliberal) approach sees informal employment as a voluntary choice. In this view, informal employment represents a cost-minimizing strategy for entrepreneurs trying to avoid the costs of labor regulations. Basically, the informal sector is viewed as the optimal and coherent response of economic units to government-induced distortions like minimum wages and excessive taxes (Chaudhuri and Mukhopadhyay 2010).

The third theory of informal employment sees the informal sector as heterogeneous and comprising at least two distinct sub-sectors: informal activities with direct subsistence goals and dynamic activities with decreasing labor costs and capital accumulation goals (see Chaudhuri and Mukhopadhyay (2010)). I argue that informal employment in Ecuador exhibits the characteristics of a heterogeneous informal market, where informal work is both a demand-led phenomenon and a voluntary and primarily supply-led form of employment. See Cunningham and Maloney (2001), Paulson and Townsend (2005), Günther and Launov (2012), and Harati (2013) for studies in developing countries that exhibit similar characteristics.

Literature relating poverty and informal employment is scarce, mostly based on studying a one-way relationship, and usually being descriptive. For instance, Gasparini and Tornarolli (2009) study the trends of labor informality in the Latin America region during the period 1989-2005. While the cross-section evidence seems to be consistent with the idea of voluntary selfemployment, the authors found that, on average, being informal implies lower wages, even when controlling for observable factors. Informally employed male workers without a secondary education earn, on average, $30 \%$ less than their formally employed counterparts. Accordingly, in all countries the difference in the poverty headcount ratio between informal and formal workers is sizeable. Loayza et al. (2009) study, among other things, the connection between poverty and informality in Latin America and the Caribbean (LAC). Using country-level data, the authors use the share of informal employment as one of the determinants of 
poverty and use instrumental variables to control for the endogeneity of informality on poverty. The results suggest that the share of the informal sector has a significant positive impact on the incidence of poverty across LAC countries. Maurizio (2012) studies to what extent the income segmentation associated with informality is a relevant factor in the poverty situation of households in Argentina, Brazil, Chile, and Peru. She finds a positive relationship between informality and poverty. However, she also finds that the elimination of informality does not eliminate poverty. A more recent study (Webster et al. 2016) looks at the relationship between informality, property rights, and poverty in three Chinese cities. Among the various definitions of informality used by the authors, the results show a strong association between labor contract types and poverty. While these results are fundamental for the understanding of informal employment and poverty, either no casual relationship between the two phenomena was established, or only a one-way relationship was considered in the analysis, usually with informality as a determinant of poverty.

To the best of this author's knowledge, only three studies have used a simultaneous equations framework to study the relationship between poverty and informality: Amuedo-Dorantes (2004), who studies the determinants of poverty and its implications for the informal sector in Chile; Devicienti et al. (2009), who study the same process using panel data for Argentina; and Nazier and Ramadan (2015), who study the inverse causality between informality and poverty in Egypt. Both studies in Latin America found a strong correlation between poverty and informality in the countries. In the absence of panel data, I follow the methodology employed by Amuedo-Dorantes (2004) and study the determinants of poverty and informality in Ecuador. In addition to the results already provided for salaried workers in Chile, I also provide estimations for selfemployed workers. These results, to date unavailable in the literature, contribute to a better understanding of the heterogeneity of informal sector employment in a developing country, where usually more than $50 \%$ of the working population is categorized as self-employed.

\section{Data and descriptive analysis}

The data used in this paper are drawn from the Ecuadorian National Living Standards Survey (ECV)
2014, conducted by the Ecuadorian National Institute of Statistics (INEC). The ECV is a cross-sectional survey representative of the Ecuadorian population. The survey collects detailed information on household demographics, health, education, occupations and labor force participation, housing and asset ownership, household food, and non-food expenditures and income.

Affiliation to the national social security system is mandatory for all salaried workers. A registered worker has access to health care services and retirement benefits. A salaried worker also has the right to earn at least the minimum wage, be paid for extra hours of work and to receive mandated benefits (teen salaries and profit sharing at the end of the fiscal year) (Canelas 2014). Since the social security card constitutes a sufficient proof of labor dependence, it assures employers' compliance with all these benefits. On the other hand, it also reduces the chances of employees under-declaring their income as the information is cross-validated between the National Revenue Tax Institute, employers and employees. Hence, the definition of informality used in this paper is based on the lack of social security coverage. Since this definition applies only to salaried workers, I run separate regressions using self-employment status as an alternative definition of informality. These results are interpreted in Section 5.

Studying the relationship between informality and poverty is a difficult task since poverty is measured at the household level while informality and other human capital variables are based on individual status. In order to deal with this problem, I follow the standard practice in the literature (Amuedo-Dorantes 2004; Devicienti et al. 2009), and I base the definition of informality on the formal/informal status of the household head. Thus, I work with a sample of working household heads.

The poverty status of the household is assessed using the index of unsatisfied basic needs (UBN) (Necesidades Basicas Insatisfechas; NBI) proposed by the United Nations Economic Commission for Latin America and the Caribbean (ECLAC) and used as an official measure of poverty in many countries in Latin America, including Ecuador. ${ }^{2}$ Most UBN indices include indicators such as access to clean

\footnotetext{
${ }^{2}$ This indicator has already been calculated by the INEC and the variable is available in the dataset.
} 
Table 1 Poverty measures

\begin{tabular}{llllrr}
\hline & $\begin{array}{l}\text { All } \\
(1)\end{array}$ & $\begin{array}{l}\text { Self-employed } \\
(2)\end{array}$ & $\begin{array}{l}\text { Salaried } \\
(3)\end{array}$ & $\begin{array}{l}\text { Salaried formal } \\
(4)\end{array}$ & $\begin{array}{l}\text { Salaried informal } \\
(5)\end{array}$ \\
\hline Unsatisfied Basic Needs (\%) & 37.90 & 44.77 & 27.88 & 22.10 & 40.46 \\
UBN (\% sample) & 37.90 & 26.57 & 11.33 & 6.15 & 5.18 \\
Consumption poverty (\%) & 28.11 & 34.72 & 18.48 & 12.80 & 30.81 \\
CP (\% sample) & 28.11 & 20.60 & 7.51 & 3.57 & 3.95 \\
\hline
\end{tabular}

Source: author's calculations based on ECV 2014

water, quality of housing, crowding, education level of household head, school attendance, nutrition, and others. In the case of Ecuador, a household is considered poor if one of the following holds:

- The house is made of irregular/inadequate materials (housing).

- The house does not have adequate services such as a flush toilet and piped water (sanitation).

- There is a high dependency ratio, with three or more persons per person working and a household head with two or fewer years of primary school education (subsistence capacity).

- There is at least one child between 6 and 12 years old who is not attending school (school attendance).

- There are more than three persons per room for sleeping (crowding).

The use of a composite index to measure poverty is not free of criticisms. The most obvious problem with the UBN is that the greater the number of indicators used to create the index, the greater the likelihood of being categorized as poor - the probability of being categorized as poor would be higher if one uses five indicators instead of three.

In order to measure the robustness of the estimates, I also present the results using a consumption poverty line. This measure is one of the official poverty lines used by the Ecuadorian government. ${ }^{3}$

Table 1 presents the percentage of poor households for different sub-samples and two measures of poverty. As mentioned before, working individuals are divided into salaried and self-employed workers. Salaried workers represent, on average, $40 \%$ of all working individuals, while the other $60 \%$ are

\footnotetext{
${ }^{3}$ The poverty status of the households was obtained using the codes provided by the INEC.
}

self-employed. The first row of Table 1 gives the percentage of poor households with respect to each sub-sample, while the second row presents the same results with respect to the entire sample of workers. For instance, using the UBN indicator, around $45 \%$ of self-employed workers and $28 \%$ of salaried workers are poor (row 1, columns 2 and 3). With respect to the whole sample, poor self-employed workers represent $27 \%$ of the sample and poor salaried workers represent $11 \%$ (row 2, columns 2 and 3). Together, poor self-employed and salaried workers comprise $38 \%$ of the sample. Columns 4 and 5 decompose the results of salaried workers into formal and informal workers. The interpretation of the results is similar to columns 2 and $3 .{ }^{4}$ Finally, the interpretation for row 3 (4), is similar to row 1 (2).

Figure 1 illustrates kernel density estimates of monthly earnings for salaried and self-employed workers (Table 2 reports the corresponding sample means along other descriptive statistics). Job income disparities between salaried and self-employed workers are clearly visible, as the earnings distribution for salaried workers is shifted to the right. Also, within salaried workers, household heads employed in the formal sector earn significantly more than their counterparts in the informal sector, as depicted in the right graph of Fig. 1.

In Fig. 2, I plot the kernel distributions of household revenues for salaried and self-employed workers. The distributions are similar to those of monthly earnings. Since household heads' earnings account, on average, for $69 \%$ of household incomes, it is not

\footnotetext{
${ }^{4}$ In the second row, the proportions showed in columns 2 and 3 add to that of column 1 , and those in columns 4 and 5 add to that in column 3 .
} 

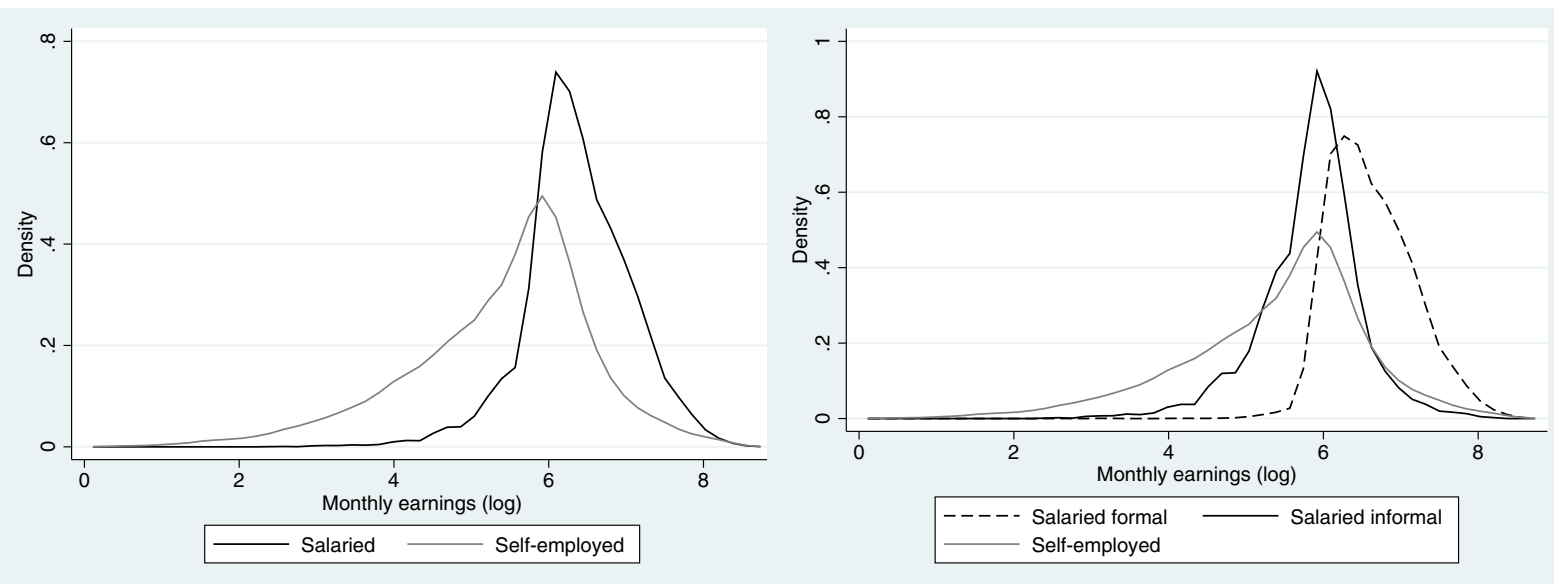

Fig. 1 Monthly earnings. Source: Author's calculation from ECV 2014

surprising to find higher poverty rates among informal workers.

\section{Empirical specification}

The aim of this article is to analyse the relationship between poverty and informal employment in Ecuador. In particular, it aims to address the following questions: Does being poor affect the probability of having informal employment? Is being an informal worker a determinant of poverty? That is, are informality and poverty interrelated? In this framework, informality and poverty are assumed to affect each other in both directions. On the one hand, informal employment affects the poverty status of the household mainly through low earnings. On the other hand, household poverty may be the main reason for a household head to accept informal employment, since they cannot afford to be unemployed.

Modeling this inverse relationship is usually challenging. First, the analysis needs to account for the potential endogeneity of household poverty and household head's informal employment status, as well as for unobserved factors that may affect these two phenomena simultaneously. Second, focusing the analysis only on working individuals raises the problem of sample selection. Third, poverty is measured at the household level, while informality and other human capital variables are based on individual status. While the latter problem is handled by focusing the analysis on a sample of household heads (see Section 3), a simultaneous equations probit model with sample selection is well suited to tackling the first two issues. The model is specified as follows:

$y_{1 i}=\gamma_{1} y_{2 i}+\beta_{1} X_{1 i}+\varepsilon_{1 i}$,

$y_{2 i}=\gamma_{2} y_{1 i}+\beta_{2} X_{2 i}+\varepsilon_{2 i}$,

$y_{3 i}=\alpha z_{i}+\varepsilon_{3 i}$,

where $y_{1 i}$ is a dummy variable indicating the $i$ th household head's employment status, i.e. formal/informal, $y_{2 i}$ is a dummy variable indicating the $i$ th household's poverty status, and $X_{j i}$ is a vector of sociodemographic and work-related characteristics of the $i$ th household head, with $j=1,2$. Equation 3 is the selection equation, thus $y_{3 i}$ is a dummy variable equal to 1 if the household head works and 0 otherwise. $z_{i}$ is a vector of sociodemographic characteristics similar to $X_{j i}$, but not equal. ${ }^{5}$ The estimation of this model is thoroughly discussed

\footnotetext{
${ }^{5}$ The selection equations include age, age squared, marital status, educational attainment, a dummy variable indicating the number of children aged less than 5 years old, a dummy variable indicating whether the respondent is attending school, whether the household is a remittance receiver, and geographical region/area dummy variables. The selection equations are identified by the exclusion from the structural equations of the dummy variables indicating whether the respondent is attending school and the number of children under the age of 5 (Amuedo-Dorantes 2004).
} 
Table 2 Descriptive statistics

\begin{tabular}{|c|c|c|c|c|c|c|c|c|c|c|}
\hline & \multicolumn{2}{|c|}{ Whole sample } & \multicolumn{2}{|c|}{ Self-employed } & \multicolumn{2}{|c|}{ Salaried workers } & \multicolumn{2}{|c|}{ Salaried informal } & \multicolumn{2}{|c|}{ Salaried formal } \\
\hline & Mean & Std. Dev. & Mean & Std. Dev. & Mean & Std. Dev. & Mean & Std. Dev. & Mean & Std. Dev. \\
\hline Monthly earnings & 523.89 & 527.05 & 382.22 & 466.59 & 730.72 & 541.70 & 414.79 & 296.22 & 875.98 & 566.61 \\
\hline Age (years) & 44.29 & 12.09 & 46.69 & 12.30 & 40.80 & 10.88 & 40.03 & 11.35 & 41.15 & 10.63 \\
\hline Gender $($ male $=1)$ & 0.79 & 0.40 & 0.78 & 0.41 & 0.81 & 0.39 & 0.73 & 0.44 & 0.84 & 0.36 \\
\hline Ethnic origin (minority = 1) & 0.20 & 0.40 & 0.23 & 0.42 & 0.14 & 0.35 & 0.17 & 0.37 & 0.13 & 0.34 \\
\hline Living in couple (yes $=1$ ) & 0.74 & 0.44 & 0.73 & 0.44 & 0.75 & 0.43 & 0.67 & 0.47 & 0.79 & 0.41 \\
\hline Hh size & 4.03 & 1.95 & 4.10 & 2.09 & 3.93 & 1.74 & 4.02 & 1.89 & 3.88 & 1.66 \\
\hline Remittances (yes = 1) & 0.03 & 0.17 & 0.04 & 0.19 & 0.02 & 0.14 & 0.03 & 0.16 & 0.02 & 0.13 \\
\hline $\begin{array}{l}\text { Number of other hh } \\
\text { members working }\end{array}$ & 0.66 & 0.82 & 0.62 & 0.84 & 0.72 & 0.79 & 0.68 & 0.82 & 0.73 & 0.77 \\
\hline Tenure (years) & 15.36 & 13.85 & 19.11 & 15.01 & 9.90 & 9.63 & 8.94 & 9.80 & 10.34 & 9.52 \\
\hline \multicolumn{11}{|l|}{ Education } \\
\hline Without formal schooling & 0.06 & 0.24 & 0.09 & 0.28 & 0.02 & 0.15 & 0.04 & 0.20 & 0.01 & 0.12 \\
\hline Some primary & 0.15 & 0.36 & 0.20 & 0.40 & 0.08 & 0.27 & 0.14 & 0.35 & 0.05 & 0.22 \\
\hline Primary completed & 0.33 & 0.47 & 0.37 & 0.48 & 0.26 & 0.44 & 0.35 & 0.48 & 0.21 & 0.41 \\
\hline Some secondary & 0.16 & 0.36 & 0.15 & 0.36 & 0.16 & 0.37 & 0.22 & 0.41 & 0.14 & 0.34 \\
\hline Secondary completed & 0.16 & 0.37 & 0.11 & 0.32 & 0.23 & 0.42 & 0.17 & 0.38 & 0.25 & 0.43 \\
\hline Post-secondary & 0.14 & 0.35 & 0.07 & 0.25 & 0.25 & 0.43 & 0.08 & 0.27 & 0.33 & 0.47 \\
\hline \multicolumn{11}{|l|}{ Area of residence $($ area $=1)$} \\
\hline Urban & 0.51 & 0.50 & 0.40 & 0.49 & 0.67 & 0.47 & 0.62 & 0.49 & 0.69 & 0.46 \\
\hline North region & 0.30 & 0.46 & 0.28 & 0.45 & 0.33 & 0.47 & 0.25 & 0.43 & 0.36 & 0.48 \\
\hline Coast region & 0.15 & 0.36 & 0.16 & 0.36 & 0.14 & 0.35 & 0.17 & 0.38 & 0.13 & 0.34 \\
\hline Central region & 0.30 & 0.46 & 0.30 & 0.46 & 0.32 & 0.47 & 0.36 & 0.48 & 0.29 & 0.46 \\
\hline South region & 0.24 & 0.43 & 0.27 & 0.44 & 0.21 & 0.41 & 0.21 & 0.41 & 0.21 & 0.41 \\
\hline \multicolumn{11}{|l|}{ Labor market } \\
\hline Small firm & 0.70 & 0.46 & 0.96 & 0.21 & 0.33 & 0.47 & 0.74 & 0.44 & 0.15 & 0.35 \\
\hline Medium firm & 0.08 & 0.27 & 0.04 & 0.19 & 0.15 & 0.35 & 0.15 & 0.35 & 0.15 & 0.35 \\
\hline Large firm & 0.22 & 0.41 & 0.01 & 0.09 & 0.52 & 0.50 & 0.11 & 0.31 & 0.71 & 0.45 \\
\hline Managers & 0.01 & 0.12 & 0.00 & 0.06 & 0.03 & 0.17 & 0.01 & 0.08 & 0.04 & 0.20 \\
\hline Professionals & 0.06 & 0.24 & 0.02 & 0.13 & 0.12 & 0.33 & 0.02 & 0.15 & 0.17 & 0.37 \\
\hline Technicians & 0.03 & 0.17 & 0.01 & 0.09 & 0.06 & 0.24 & 0.02 & 0.14 & 0.08 & 0.28 \\
\hline Office workers & 0.02 & 0.15 & 0.00 & 0.06 & 0.05 & 0.22 & 0.02 & 0.14 & 0.06 & 0.25 \\
\hline Service workers & 0.15 & 0.36 & 0.14 & 0.35 & 0.17 & 0.37 & 0.15 & 0.36 & 0.18 & 0.38 \\
\hline Skilled agricultural workers & 0.29 & 0.45 & 0.43 & 0.49 & 0.09 & 0.29 & 0.11 & 0.31 & 0.08 & 0.27 \\
\hline Craft and related trades workers & 0.15 & 0.36 & 0.16 & 0.37 & 0.15 & 0.36 & 0.24 & 0.43 & 0.10 & 0.31 \\
\hline Plant and machine operators & 0.10 & 0.30 & 0.07 & 0.25 & 0.15 & 0.35 & 0.17 & 0.38 & 0.13 & 0.34 \\
\hline Elementary occupations workers & 0.17 & 0.38 & 0.17 & 0.37 & 0.18 & 0.39 & 0.26 & 0.44 & 0.15 & 0.35 \\
\hline Agriculture & 0.36 & 0.48 & 0.51 & 0.50 & 0.13 & 0.34 & 0.16 & 0.36 & 0.12 & 0.33 \\
\hline Mining & 0.02 & 0.12 & 0.00 & 0.05 & 0.03 & 0.18 & 0.03 & 0.18 & 0.03 & 0.18 \\
\hline Manufacturing & 0.10 & 0.30 & 0.07 & 0.26 & 0.14 & 0.34 & 0.15 & 0.36 & 0.13 & 0.33 \\
\hline
\end{tabular}


Table 2 (continued)

\begin{tabular}{|c|c|c|c|c|c|c|c|c|c|c|}
\hline & \multicolumn{2}{|c|}{ Whole sample } & \multicolumn{2}{|c|}{ Self-employed } & \multicolumn{2}{|c|}{ Salaried workers } & \multicolumn{2}{|c|}{ Salaried informal } & \multicolumn{2}{|c|}{ Salaried formal } \\
\hline & Mean & Std. Dev. & Mean & Std. Dev. & Mean & Std. Dev. & Mean & Std. Dev. & Mean & Std. Dev. \\
\hline Construction & 0.10 & 0.30 & 0.11 & 0.32 & 0.07 & 0.26 & 0.11 & 0.31 & 0.06 & 0.23 \\
\hline Commerce and trade & 0.12 & 0.32 & 0.13 & 0.33 & 0.10 & 0.30 & 0.12 & 0.33 & 0.09 & 0.28 \\
\hline Transport and communications & 0.07 & 0.26 & 0.07 & 0.26 & 0.08 & 0.27 & 0.13 & 0.34 & 0.05 & 0.22 \\
\hline Services & 0.20 & 0.40 & 0.07 & 0.26 & 0.39 & 0.49 & 0.17 & 0.37 & 0.49 & 0.50 \\
\hline Observations & \multicolumn{2}{|c|}{22,103} & \multicolumn{2}{|c|}{13,118} & \multicolumn{2}{|l|}{8,985} & \multicolumn{2}{|l|}{2,830} & \multicolumn{2}{|l|}{6,155} \\
\hline
\end{tabular}

Values are proportions between 0 and 1, unless otherwise specified; income data in USD

Source: Author's calculations based on ECV 2014

by Mallar (1977). ${ }^{6}$ The model is estimated as a simultaneous equations maximum likelihood probit model with sample selection. Corrected standard errors are obtained by bootstrapping (1200 repetitions).

\subsection{Explanatory variables}

The variables used for the estimation are standard in the literature. In Eqs. 1 and 2, I control for economic sectors (ten classified according to the UN International Standard Industrial Classification), occupations (nine classified according to the ILO International Standard Classification of Occupations), tenure, tenure squared, gender of the household head, age of the household head, age squared, ethnic origin of the household head, educational attainment (six categories), whether the household is a remittance receiver, household size, share of other household members working, share of other household members working formally, firm-size variables, whether the household is located in an urban area, and geographical region. ${ }^{7}$

Equation 1 is identified by the exclusion of the number of other household members working and the dummy variable indicating the ethnic origin of the household head. While both of these variables are highly correlated with household poverty, they do not affect by themselves the decision to accept informal employment other than through household poverty. The approach builds on Amuedo-Dorantes (2004), arguing that these household-specific variables influence one's behavior in the labor market only through

\footnotetext{
${ }^{6}$ See also Maddala (1983).

${ }^{7}$ See variables definition on the Appendix.
}

household poverty, which captures households' difficulty in covering the minimum living requirements defined by the poverty line-see also Nazier and Ramadan (2015).

Equation 2 is identified by the exclusion of the dummy variables indicating the size of the firm (with small size as the reference category). Again, while these variables are expected to affect the likelihood of working informally, they are not by themselves determinants of household poverty other than through the type of job held by the household head. ${ }^{8}$ Table 8 presents the definition for each variable used in the estimation.

The logic behind the use of these variables is that individual characteristics such as the respondent's age, tenure and education are found to affect both informality and poverty. More experienced and educated workers are supposed to be more productive and have access to better-paid jobs. Firm and regional characteristics are also important. For instance, smaller firms with limited access to capital markets might be more inclined to hire workers on an informal basis in order to reduce labor-related costs. Industry of activity may also affect the duration of the services. Jobs in construction, tourism and agricultural sectors are characterized by their relatively short duration. In addition, poverty is mostly concentrated in rural areas that are mainly characterized by agricultural employment.

Finally, household characteristics such as household size and the number of household members working are also expected to affect the likelihood of poverty. For instance, while poverty increases with household size, it decreases with more household

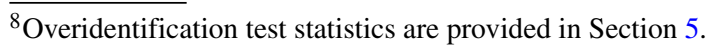



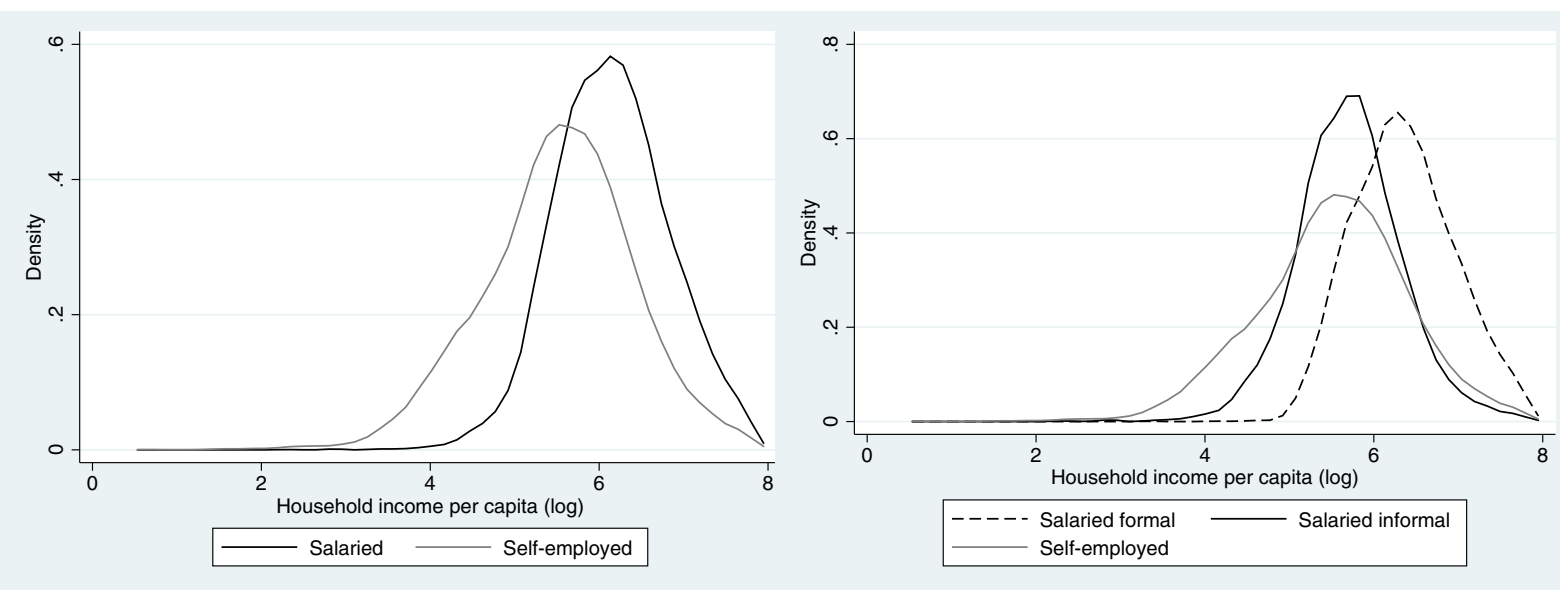

Fig. 2 Household revenue. Source: Author's calculation from ECV 2014

members working, due to their contribution to household income. However, with an increasing number of household members working informally, the likelihood of poverty may increase if informal work is coupled with low earnings.

\section{Results}

\subsection{Salaried workers}

Table 3 presents the results from the joint estimation of Eqs. 1 and 2. Several findings are worth discussing. First of all, both the poverty status and the informal employment condition of the household head have a positive and significant effect on the informality and poverty equations, respectively. That is, poor household heads are more likely to work informally, and household heads having informal employment, as wage or salaried employees, are more likely to be poor. These results are in line with those found by Amuedo-Dorantes (2004) in Chile and Devicienti et al. (2009) in Argentina.

Second, one can see that informal salaried work is less likely among more tenured household heads. Indeed, experience is of high value in a market in which $50 \%$ of workers have acquired, at most, primary school education. In this respect, the role of education is of particular importance, since the higher the level of education the less likely is the household head to work informally, and also the less likely she or he is to be poor. In fact, having post-secondary education decreases the probability of being an informal salaried worker by $20 \%$ and the probability of being poor by the same proportion, compared to those workers without formal education.

Informal salary employment is more frequent in low-productivity and low-income sectors in which low-skilled workers are in higher demand. This is, for instance, the case of the transportation and construction sectors, and for small firms that may need to reduce labor costs. Indeed, medium- and large-size firms, compared to small firms, are subject to more institutional control and face the prospect of disciplinary action from the government. Thus, informal salaried work is less likely to occur there. This fact is also confirmed from the descriptive statistics- $74 \%$ of informal salaried work is concentrated in small firms.

It is also interesting to see how minorities (AfroAmerican and indigenous people) are more likely to be in poverty than mestizos or white people. Ethnic segregation is a common feature of the Ecuadorian labor market. It is stronger when one takes into account that ethnic minorities face pre-market discrimination. They have, in general, limited access to education and health services, and are concentrated mainly in rural areas (Canelas and Salazar 2014; Atal et al. 2009).

Finally, the regional dummies capture geographical differences and region-specific shocks that influence the informality and poverty status of the household. For instance, household poverty, as measured by the IBN index, is more frequent in the coastal region than in the rest of the country. The coastal region 
Table 3 Simultaneous equation probit model: salaried workers

\begin{tabular}{|c|c|c|c|c|c|c|c|c|}
\hline & \multicolumn{4}{|c|}{ Informal employment } & \multicolumn{4}{|c|}{ Household poverty } \\
\hline & Coef. & Std. & Mg. effect & Std. & Coef. & Std. & $\mathrm{Mg}$. effect & Std. \\
\hline Household poverty & $0.176^{*}$ & 0.083 & $0.052 *$ & 0.024 & & & & \\
\hline Informal employment & & & & & $0.091 * * *$ & 0.023 & $0.027 * * *$ & 0.007 \\
\hline Age & $-0.058 * * *$ & 0.014 & $-0.017 * * *$ & 0.004 & $-0.076^{* * *}$ & 0.012 & $-0.023 * * *$ & 0.004 \\
\hline Age squared & $0.001 * * *$ & 0.000 & $0.000 * * *$ & 0.000 & $0.001 * * *$ & 0.000 & $0.000 * * *$ & 0.000 \\
\hline Living in couple (yes $=1$ ) & $-0.154 * * *$ & 0.068 & $-0.047 * * *$ & 0.021 & $-0.051 * * *$ & 0.059 & $-0.015^{* * *}$ & 0.018 \\
\hline Gender $($ male $=1)$ & $-0.315^{* * *}$ & 0.131 & $-0.099 * * *$ & 0.044 & $0.195 * * *$ & 0.065 & $0.056^{* * *}$ & 0.018 \\
\hline Ethnic origin (minority $=1$ ) & & & & & $0.410 * * *$ & 0.047 & $0.135^{* * *}$ & 0.017 \\
\hline Household size & $0.037 * * *$ & 0.018 & $0.011 * * *$ & 0.005 & $0.204 * * *$ & 0.011 & $0.061 * * *$ & 0.003 \\
\hline Number of hh members working & & & & & $-0.167 * * *$ & 0.024 & $-0.050 * * *$ & 0.007 \\
\hline Share of hh members working formally & $-0.398 * * *$ & 0.072 & $-0.117 * * *$ & 0.021 & $-0.307 * * *$ & 0.053 & $-0.092 * * *$ & 0.016 \\
\hline Remittance receiver household & 0.177 & 0.189 & 0.055 & 0.063 & -0.171 & 0.127 & -0.048 & 0.033 \\
\hline \multicolumn{9}{|c|}{ Education level (ref. without formal schooling) } \\
\hline Some primary & -0.064 & 0.120 & -0.018 & 0.034 & $-0.029 * * *$ & 0.110 & $-0.009 * * *$ & 0.032 \\
\hline Primary completed & $-0.307 * * *$ & 0.154 & $-0.085 * * *$ & 0.040 & $-0.330 * * *$ & 0.102 & $-0.093 * * *$ & 0.027 \\
\hline Some secondary & $-0.346^{* * *}$ & 0.190 & $-0.092 * * *$ & 0.045 & $-0.398 * * *$ & 0.105 & $-0.106 * * *$ & 0.025 \\
\hline Secondary completed & $-0.585^{* * *}$ & 0.279 & $-0.150 * * *$ & 0.061 & $-0.590 * * *$ & 0.109 & $-0.154 * * *$ & 0.024 \\
\hline Post-secondary & $-0.802 * * *$ & 0.396 & $-0.198 * * *$ & 0.079 & $-0.772 * * *$ & 0.121 & $-0.195 * * *$ & 0.025 \\
\hline Tenure & $-0.041^{* * *}$ & 0.006 & $-0.012 * * *$ & 0.002 & $-0.015 * * *$ & 0.005 & $-0.005^{* * *}$ & 0.002 \\
\hline Tenure squared & $0.001 * * *$ & 0.000 & $0.000 * * *$ & 0.000 & $0.000 * * *$ & 0.000 & 0.000 & 0.000 \\
\hline Medium firm & $-0.926 * * *$ & 0.051 & $-0.202 * * *$ & 0.009 & & & & \\
\hline Large firm & $-1.782 * * *$ & 0.047 & $-0.508 * * *$ & 0.012 & & & & \\
\hline \multicolumn{9}{|l|}{ Economic sectors (ref. services) } \\
\hline Mines & $0.559 * * *$ & 0.101 & $0.193 * * *$ & 0.039 & $0.253 * *$ & 0.087 & $0.082 * *$ & 0.030 \\
\hline Manufacturing & $0.149 * *$ & 0.066 & $0.046^{* *}$ & 0.021 & -0.021 & 0.059 & -0.006 & 0.018 \\
\hline Construction & $0.390 * * *$ & 0.077 & $0.129 * * *$ & 0.028 & 0.124 & 0.072 & 0.039 & 0.023 \\
\hline Commerce & 0.086 & 0.068 & 0.026 & 0.021 & $0.129 * *$ & 0.060 & $0.040 * *$ & 0.019 \\
\hline Transportation & $0.739 * * *$ & 0.076 & $0.260 * * *$ & 0.029 & 0.071 & 0.078 & 0.022 & 0.024 \\
\hline Agriculture & $0.263 * *$ & 0.088 & $0.083 * *$ & 0.029 & $0.264 * * *$ & 0.073 & $0.085^{* * *}$ & 0.025 \\
\hline Other & 0.158 & 0.091 & 0.049 & 0.030 & 0.027 & 0.081 & 0.008 & 0.025 \\
\hline \multicolumn{9}{|l|}{ Occupations (ref. skill-agricultural workers) } \\
\hline Managers & 0.033 & 0.179 & 0.010 & 0.054 & $-0.399 * *$ & 0.156 & $-0.102 * *$ & 0.033 \\
\hline Professionals & 0.229 & 0.141 & 0.072 & 0.047 & -0.002 & 0.117 & -0.001 & 0.035 \\
\hline Technicians & 0.085 & 0.139 & 0.026 & 0.043 & $-0.263 * *$ & 0.111 & $-0.072 * *$ & 0.027 \\
\hline Office workers & -0.142 & 0.138 & -0.040 & 0.037 & -0.187 & 0.109 & -0.052 & 0.028 \\
\hline Service workers & 0.180 & 0.102 & 0.055 & 0.033 & -0.068 & 0.085 & -0.020 & 0.024 \\
\hline Craft and related trades workers & $0.517 * * *$ & 0.096 & $0.171 * * *$ & 0.035 & -0.033 & 0.088 & -0.010 & 0.026 \\
\hline Plant and machine operators & $0.266 * *$ & 0.099 & $0.084 * *$ & 0.033 & $-0.224 * *$ & 0.086 & $-0.063^{* *}$ & 0.022 \\
\hline Elementary occupations workers & 0.170 & 0.087 & 0.052 & 0.028 & 0.017 & 0.079 & 0.005 & 0.024 \\
\hline Urban & -0.032 & 0.170 & -0.010 & 0.050 & -0.491 & 0.036 & -0.155 & 0.012 \\
\hline
\end{tabular}


Table 3 (continued)

\begin{tabular}{|c|c|c|c|c|c|c|c|c|}
\hline & \multicolumn{4}{|c|}{ Informal employment } & \multicolumn{4}{|c|}{ Household poverty } \\
\hline & Coef. & Std. & Mg. effect & Std. & Coef. & Std. & Mg. effect & Std. \\
\hline \multicolumn{9}{|l|}{ Regions (ref. coastal region) } \\
\hline North region & $-0.338 * * *$ & 0.075 & $-0.095^{* * *}$ & 0.020 & $-0.622 * * *$ & 0.042 & $-0.170 * * *$ & 0.010 \\
\hline Central region & 0.072 & 0.090 & 0.022 & 0.028 & $-0.731 * * *$ & 0.052 & $-0.174 * * *$ & 0.009 \\
\hline South region & -0.051 & 0.075 & -0.015 & 0.021 & $-0.596 * * *$ & 0.048 & $-0.154 * * *$ & 0.010 \\
\hline$R$ squared & 0.0002 & & & & 0.0001 & & & \\
\hline No. observations & 8,985 & & & & 8,985 & & & \\
\hline Overidentification test $\left(\mathrm{nR}^{2}\right)$ & 1.797 & & & & 0.8985 & & & \\
\hline$\chi_{2}^{2}$ at $5 \%$ significance level & 5.991 & & & & 5.991 & & & \\
\hline
\end{tabular}

Bootstrapped standard errors. 1200 repetitions; $* * * p<0.001, * * p<0.01, * p<0.05$

employs low-skilled labor for agriculture and fishing, particularly on cacao and banana plantations, rice fields, in the tuna industry and on shrimp farms. The high dependence on agriculture and fishing and its geographical location makes the region more vulnerable to natural phenomena such as El Niño, which in turn increases the incidence of poverty. In addition to this, the economy relies heavily on tourism, making the labor market more inclined towards shortterm/seasonal occupations than the rest of the country. On the other hand, informal salaried work seems $10 \%$ less likely in the northern region of the country compared to the coastal region, and equally likely in all other regions.

These findings support the view of informal salaried work as a second-best strategy that substitutes for the lack of formal employment and to which individuals turn when they face difficulties meeting their basic needs. Labor formalization in the covered sector in Ecuador has notably increased in recent years. According to Cruces et al. (2015), the percentage of wage/salaried workers registered with the system's contributory scheme rose from $33.0 \%$ in 2003 to $54.7 \%$ in 2012. A recent report from the ILO (2014) attributes the positive trend in wage labor formalization, mostly since 2007 , to a set of policies designed to improve working conditions. The measures include, among other things, the expansion of health insurance for children under the age of 18 and spouses of registered workers, mortgage loans for affiliated members, an active minimum wage policy and the strengthening of labor inspection offices. It is therefore possible that those workers who remain informal have no other option than to do so.

\subsection{Self-employed}

The previous analysis focused only on salaried employees, with the definition of informality relying on whether the firms in which these employees work comply with the legislation. However, as mentioned above, salaried workers represent only $40 \%$ of the working population. The remaining $60 \%$ are self-employed workers.

Since this group of workers is more heterogeneous than the group of salaried workers, as shown in the descriptive statistics, estimating the determinants of self-employment will provide us with a clearer picture of the informal sector in the country.

Table 4 shows the results of the joint estimation of Eqs. 1 and 2 using the whole sample of workers. Several points are worth noting. First, both the poverty status and informal employment condition of the household head have a positive and significant effect on the informality and poverty equations, respectively. This is similar to the results of the estimations using only salaried workers (specification 1). However, the marginal effect of poverty on informal employment is multiplied by two in this specification.

Second, more educated persons seem more likely to work informally (being self-employed). Similarly, professional workers are also more likely to be 
Table 4 Simultaneous equation probit model: all workers

\begin{tabular}{|c|c|c|c|c|c|c|c|c|}
\hline & \multicolumn{4}{|c|}{ Informal employment } & \multicolumn{4}{|c|}{ Household poverty } \\
\hline & Coef. & Std. & Mg. effect & Std. & Coef. & Std. & Mg. effect & Std. \\
\hline Household poverty & $0.243 * * *$ & 0.061 & $0.095 * * *$ & 0.024 & & & & \\
\hline Informal employment & & & & & $0.039 * * *$ & 0.011 & $0.014 * * *$ & 0.004 \\
\hline Age & $0.071 * * *$ & 0.012 & $0.028 * * *$ & 0.005 & $-0.062 * * *$ & 0.007 & $-0.023 * * *$ & 0.003 \\
\hline Age squared & $-0.001 * * *$ & 0.000 & $0.000 * * *$ & 0.000 & $0.000 * * *$ & 0.000 & $0.000 * * *$ & 0.000 \\
\hline Living in couple (yes = 1 ) & $0.197 * * *$ & 0.044 & $0.078 * * *$ & 0.018 & $-0.205^{* * *}$ & 0.033 & $-0.077 * * *$ & 0.012 \\
\hline Gender $($ male $=1)$ & $-0.169 * *$ & 0.075 & $-0.066^{* *}$ & 0.029 & $0.210 * * *$ & 0.036 & $0.075^{* * *}$ & 0.012 \\
\hline Ethnic origin (minority = 1) & & & & & $0.402 * * *$ & 0.026 & $0.153 * * *$ & 0.010 \\
\hline Number of hh members working & & & & & $-0.184 * * *$ & 0.015 & $-0.067 * * *$ & 0.006 \\
\hline Share of hh members working formally & $-0.255^{* * *}$ & 0.037 & $-0.100 * * *$ & 0.014 & $-0.169 * * *$ & 0.030 & $-0.062 * * *$ & 0.011 \\
\hline Household size & -0.018 & 0.013 & -0.007 & 0.005 & $0.183 * * *$ & 0.006 & $0.067 * * *$ & 0.002 \\
\hline Remittance receiver household & $0.221 * *$ & 0.078 & $0.084 * *$ & 0.029 & $-0.451 * * *$ & 0.066 & $-0.147 * * *$ & 0.019 \\
\hline \multicolumn{9}{|c|}{ Education level (ref. without formal schooling) } \\
\hline Some primary & 0.037 & 0.070 & 0.014 & 0.027 & $-0.255^{* * *}$ & 0.046 & $-0.090 * * *$ & 0.015 \\
\hline Primary completed & 0.107 & 0.078 & 0.042 & 0.031 & $-0.626 * * *$ & 0.043 & $-0.215^{* * *}$ & 0.014 \\
\hline Some secondary & 0.135 & 0.084 & 0.053 & 0.032 & $-0.682 * * *$ & 0.048 & $-0.218 * * *$ & 0.013 \\
\hline Secondary completed & $0.200 * * *$ & 0.093 & $0.077 * * *$ & 0.035 & $-0.873 * * *$ & 0.052 & $-0.266 * * *$ & 0.012 \\
\hline Post-secondary & $0.370^{* * *}$ & 0.109 & $0.140 * * *$ & 0.039 & $-1.097 * * *$ & 0.062 & $-0.310 * * *$ & 0.012 \\
\hline Tenure & $0.030 * * *$ & 0.003 & $0.012 * * *$ & 0.001 & $-0.013 * * *$ & 0.003 & $-0.005 * * *$ & 0.001 \\
\hline Tenure squared & $0.000 * * *$ & 0.000 & $0.000 * * *$ & 0.000 & $0.000 * * *$ & 0.000 & $0.000 * * *$ & 0.000 \\
\hline Medium firm & $-1.541 * * *$ & 0.038 & $-0.512 * * *$ & 0.008 & & & & \\
\hline Large firm & $-2.766 * * *$ & 0.051 & $-0.759 * * *$ & 0.005 & & & & \\
\hline \multicolumn{9}{|l|}{ Economic sectors (ref. services) } \\
\hline Mines & -0.195 & 0.145 & -0.078 & 0.058 & $0.335 * * *$ & 0.080 & $0.129 * * *$ & 0.032 \\
\hline Manufacturing & $0.365 * * *$ & 0.056 & $0.137 * * *$ & 0.020 & -0.042 & 0.048 & -0.015 & 0.017 \\
\hline Construction & $1.101 * * *$ & 0.059 & $0.350 * * *$ & 0.013 & 0.057 & 0.053 & 0.021 & 0.020 \\
\hline Commerce & $0.400 * * *$ & 0.042 & $0.150 * * *$ & 0.015 & -0.014 & 0.045 & -0.005 & 0.017 \\
\hline Transportation & $0.717 * * *$ & 0.065 & $0.250 * * *$ & 0.019 & 0.058 & 0.057 & 0.022 & 0.021 \\
\hline Agriculture & $1.206^{* * *}$ & 0.071 & $0.429 * * *$ & 0.021 & $0.307 * * *$ & 0.053 & $0.114 * * *$ & 0.020 \\
\hline Other & $-0.517 * * *$ & 0.059 & $-0.204 * * *$ & 0.022 & 0.054 & 0.060 & 0.020 & 0.022 \\
\hline \multicolumn{9}{|l|}{ Occupations (ref. skill-agricultural workers): } \\
\hline Managers & 0.032 & 0.145 & 0.013 & 0.056 & $-0.499 * * *$ & 0.129 & $-0.160 * * *$ & 0.034 \\
\hline Professionals & $0.216^{*}$ & 0.104 & $0.083^{*}$ & 0.039 & -0.145 & 0.082 & -0.051 & 0.028 \\
\hline Technicians & 0.049 & 0.113 & 0.019 & 0.044 & $-0.337 * * *$ & 0.088 & $-0.114 * * *$ & 0.027 \\
\hline Office workers & $-0.539 * * *$ & 0.129 & $-0.212 * * *$ & 0.049 & $-0.237 * *$ & 0.091 & $-0.082 * *$ & 0.029 \\
\hline Service workers & $0.506^{* * *}$ & 0.074 & $0.188 * * *$ & 0.025 & $-0.134 * *$ & 0.056 & $-0.048^{* *}$ & 0.020 \\
\hline Craft and related trades workers & -0.001 & 0.073 & 0.000 & 0.029 & -0.037 & 0.056 & -0.013 & 0.020 \\
\hline Plant and machine operators & $-0.262 * *$ & 0.086 & $-0.104 * *$ & 0.034 & $-0.254 * * *$ & 0.061 & $-0.089 * * *$ & 0.020 \\
\hline Elementary occupations workers & $0.200 * * *$ & 0.059 & $0.077 * * *$ & 0.022 & 0.063 & 0.040 & 0.023 & 0.015 \\
\hline Urban & 0.090 & 0.051 & 0.035 & 0.020 & -0.551 & 0.024 & -0.200 & 0.009 \\
\hline
\end{tabular}


Table 4 (continued)

\begin{tabular}{|c|c|c|c|c|c|c|c|c|}
\hline & \multicolumn{4}{|c|}{ Informal employment } & \multicolumn{4}{|c|}{ Household poverty } \\
\hline & Coef. & Std. & Mg. effect & Std. & Coef. & Std. & Mg. effect & Std. \\
\hline \multicolumn{9}{|l|}{ Regions (ref. coastal region) } \\
\hline North region & $0.163 * * *$ & 0.044 & $0.063 * * *$ & 0.017 & $-0.584 * * *$ & 0.026 & $-0.200 * * *$ & 0.008 \\
\hline Central region & 0.055 & 0.058 & 0.022 & 0.022 & $-0.772 * * *$ & 0.032 & $-0.241 * * *$ & 0.008 \\
\hline South region & $0.290 * * *$ & 0.051 & $0.111 * * *$ & 0.019 & $-0.641 * * *$ & 0.027 & $-0.214 * * *$ & 0.008 \\
\hline$R$ squared & 0.0000 & & & & 0.0000 & & & \\
\hline No. observations & 22,103 & & & & 22,103 & & & \\
\hline Overidentification test $\left(\mathrm{nR}^{2}\right)$ & 0.0000 & & & & 0.0000 & & & \\
\hline$\chi_{2}^{2}$ at $5 \%$ significance level & 5.991 & & & & 5.991 & & & \\
\hline
\end{tabular}

Bootstrapped standard errors. 1200 repetitions; $* * * p<0.001, * * p<0.01, * p<0.05$

self-employed. This result is worth discussing since, together with the positive significant coefficient of household poverty, it suggests that neither segmented nor competitive labor market models may entirely explain the causes and consequences of informal work in the country. In other words, it suggests that the Ecuadorian labor market is composed of at least two sub-segments. The first is mostly characterized by economically constrained workers, probably lowskilled, for whom the economic status of the household plays a role in the decision to work informally. The second sub-segment is composed of those highskilled workers for whom economic constraints, here captured by poverty status, may not be the reason for becoming self-employed. Indeed, it is possible that high-skilled workers in Ecuador have an incentive to become self-employed, if by doing so they end up with higher earnings, more satisfaction in their jobs and/or better working conditions (e.g., flexible working hours) than if they were salaried workers.

This paper argues that the Ecuadorian labor market exhibits the characteristics of a heterogeneous market, in which informal work is both a demandled phenomenon and a voluntary and primarily supply-led form of employment-i.e., a last-resource option for low-skilled and income-constrained workers and a voluntary choice for more educated and entrepreneurial ones.

Finally, it is worth noting the effect of remittances not only in alleviating poverty but also in increasing the likelihood of self-employment. In the late 1990s, Ecuador suffered one of the worst macroeconomic and financial crises in its history, which resulted in the adoption of the US dollar in January 2000. The destruction of wealth in the wake of the crisis and the concomitant loss of jobs set off the largest emigration wave in Ecuador's history (Jacome 2004). As a consequence, during the first half of the 2000s, the amount of remittances received by Ecuador was comparable to oil revenues and allowed households to recover from the crisis. Since access to credit markets is limited in the country, it is possible that remittances have played an important role in alleviating liquidity constraints faced by Ecuadorian entrepreneurs. However, more research is needed concerning the mechanisms through which remittances affect self-employment.

\subsection{Low-skilled versus high-skilled workers}

To further study the effects of education on poverty and self-employment, Eqs. 1 and 2 are re-estimated separately for workers with less than secondary education and for those with secondary or post-secondary education. These estimates are particularly important as they shed more light on the hypothesis of a heterogeneous labor market in Ecuador.

The results in Table 5 show that poverty increases the likelihood of informal work among low-skilled workers by $10 \%$, and that it has no significant effect on informal work among high-skilled workers, suggesting that for this group of workers the motivations for self-employment are not related to the economic status of the household.

From a policy perspective, this result shows the heterogeneity of the Ecuadorian labor market and the 
Table 5 Simultaneous equation probit model by educational level

\begin{tabular}{|c|c|c|c|c|}
\hline & \multicolumn{2}{|c|}{ Self-employment } & \multicolumn{2}{|c|}{ Household poverty } \\
\hline & Coef. & Mg. effect & Coef. & Mg. effect \\
\hline \multicolumn{5}{|l|}{ High-skill workers } \\
\hline & 0.097 & 0.022 & 0.005 & 0.001 \\
\hline & $(0.125)$ & $(0.029)$ & $(0.017)$ & $(0.004)$ \\
\hline \multicolumn{5}{|l|}{ Low-skill workers } \\
\hline & $0.270 * * *$ & $0.086 * * *$ & $0.054 * * *$ & $0.022 * * *$ \\
\hline & $(0.074)$ & $(0.023)$ & $(0.014)$ & $(0.006)$ \\
\hline \multicolumn{5}{|l|}{ Overidentification test $\left(\mathrm{n} R^{2}\right)$} \\
\hline High-skill workers & 2.673 & & 0.668 & \\
\hline Low-skill workers & 0.000 & & & 0.000 \\
\hline$\chi_{2}^{2}$ at $5 \%$ significance level & 5.991 & & 5.991 & \\
\hline
\end{tabular}

Bootstrapped standard errors. 1200 repetitions

$* * * p<0.001, * * p<0.01, * p<0.05$

need for public policies targeting specific groups of workers.

\section{Robustness checks}

\subsection{Consumption poverty line}

As discussed in Section 3, the use of the UBN indicator to define poverty is not free from criticism, mainly because the likelihood of being categorized as poor when using the UBN may increase with the number of variables used to construct the index.

In order to verify the validity of the results, I reestimate Eqs. 1 and 2 using the official consumption poverty line as a measure of poverty. The estimates, presented in Table 6, reinforce again the main conclusion of the paper.

\subsection{Different specifications}

In the specification used above, I have controlled for the double causality between poverty and informality using a simultaneous maximum likelihood probit model. In order to verify the validity of the results, I also estimate Eqs. 1 and 2 using three different specifications, for both informal salaried workers and selfemployed. Columns 1-4 of Table 7 show the results of the univariate probit model without controlling for endogeneity. In columns 5-8, endogeneity is corrected by means of a maximum likelihood bivariate probit model. The last two columns show the results using a 2SLS linear IV model. The validity of the exclusion restrictions is not directly testable in the bivariate probit model, so I report diagnostic tests for the linear probability model using the same set of instruments as in Section $4 .^{9}$

While the estimates have different coefficients, as for salaried workers, their sign and significance level remain similar to the previous estimates in all specifications, and thus the main conclusion of the paper, for this group of workers, remains unchanged.

Regarding the estimates using self-employment as the definition of informality, the only results that differ from those in Section 5 are those using the univariate probit model. In fact, while self-employment is still positive and statistically significant in the poverty equation, the role of poverty in the likelihood of informal employment is less clear. Depending on the definition of poverty used, the variable is either positive or negative, but in both cases it is not statistically significant. These results highlight the importance of taking into account the simultaneous two-way relationship between these two phenomena.

\footnotetext{
${ }^{9}$ See Angrist (2001) and Heckman (1978) for a discussion of the methods.
} 
Table 6 Simultaneous equation probit model: consumption poverty line

\begin{tabular}{|c|c|c|c|c|c|c|c|c|}
\hline & \multicolumn{4}{|c|}{ Salaried workers } & \multicolumn{4}{|c|}{ All workers } \\
\hline & \multicolumn{2}{|c|}{ Informal employment } & \multicolumn{2}{|c|}{ Household poverty } & \multicolumn{2}{|c|}{ Informal employment } & \multicolumn{2}{|c|}{ Household poverty } \\
\hline & Coef. & Mg. effect & Coef. & Mg. effect & Coef. & Mg. effect & Coef. & Mg. effect \\
\hline & $0.158 *$ & $0.046^{*}$ & $0.176 * * *$ & $0.028 * * *$ & $0.228 * * *$ & $0.090 * * *$ & $0.086 * * *$ & $0.023 * * *$ \\
\hline & $(0.080)$ & $(0.024)$ & $(0.026)$ & $(0.004)$ & $(0.058)$ & $(0.023)$ & $(0.012)$ & $(0.003)$ \\
\hline$R$ squared & 0.0002 & & 0.0003 & & 0.0000 & & 0.0000 & \\
\hline No. observations & 8,985 & & 8,985 & & 22,103 & & 22,103 & \\
\hline Overidentification test $\left(\mathrm{nR}^{2}\right)$ & 1.797 & & 2.696 & & 0.0000 & & 0.0000 & \\
\hline$\chi_{2}^{2}$ at $5 \%$ significance level & 5.991 & & 5.991 & & 5.991 & & 5.991 & \\
\hline
\end{tabular}

Bootstrapped standard errors. 1200 repetitions; $* * * p<0.001, * * p<0.01$, * $p<0.05$

\section{Discussion}

These results show, first, the relevance of poverty for both informal salaried work and self-employment in Ecuador. In particular, household poverty, as measured both by the IBN index and household consumption, increases the likelihood of engaging in informal salaried work and self-employment by around 5 and $10 \%$, respectively. ${ }^{10}$ This finding, along with the concentration of informal workers in low-productivity and low-income sectors, supports the view of informal work as a second-best strategy that substitutes for the lack of formal employment and to which individuals turn when they face difficulties meeting their basic needs. Indeed, in the absence of unemployment benefits, workers have no choice but to work, even if they have to do it informally-in particular, when the fraction of non-labor income is small, as it is in Ecuador.

Nonetheless, as noted by Cortés Aguilar et al. (2013), at least in Latin American countries, the categories of informality and self-employment are too broad to be conclusive. Indeed, when looking at the determinants of self-employment one notices that high-skilled workers, proxied by educational level, are $12 \%$ more likely to be self-employed than those without formal education. Further, when the sample is divided into low- and high-skilled workers, the results show that poverty increases the likelihood of

\footnotetext{
${ }^{10}$ Similar results were found for informal salaried work in Chile (3-6\%).
}

informal work among low-skilled workers by around $10 \%$, and that it has no significant effect on informal work among high-skilled workers. These findings support the view of informal work as a voluntary choice for this group of workers.

While, on average, informal employment is associated with lower earnings than formal employment, as shown in Table 2, the evidence also shows that this is not the case for all groups of workers. As shown in Fig. 1, there is an overlap between the earnings distribution of formal and informal workers.

Additionally, non-monetary incentives are likely to play a role. The study of Cortés Aguilar et al. (2013) on job satisfaction among different Latin American countries shows, among other things, that selfemployed professionals and business owners are more satisfied than salaried workers with their incomes, while self-employed farmers and fisherman are less satisfied with their jobs and incomes. Along this line, a report from the World Bank (2012) found that being their "own boss" and having "flexible time schedules" are the main motivations for informality across smallfirm owners and entrepreneurs in Ecuador. The study also reports that only around $30 \%$ of this group cite the inability to find wage employment as a reason for informality. This evidence, coupled with the results of this study, reinforce the idea of a heterogeneous labor market in which some workers are better-off as self-employed while others are worse-off.

Second, the results also show that both informal salaried work and self-employment increase the likelihood of household poverty by 3 and $2 \%$, respectively. 


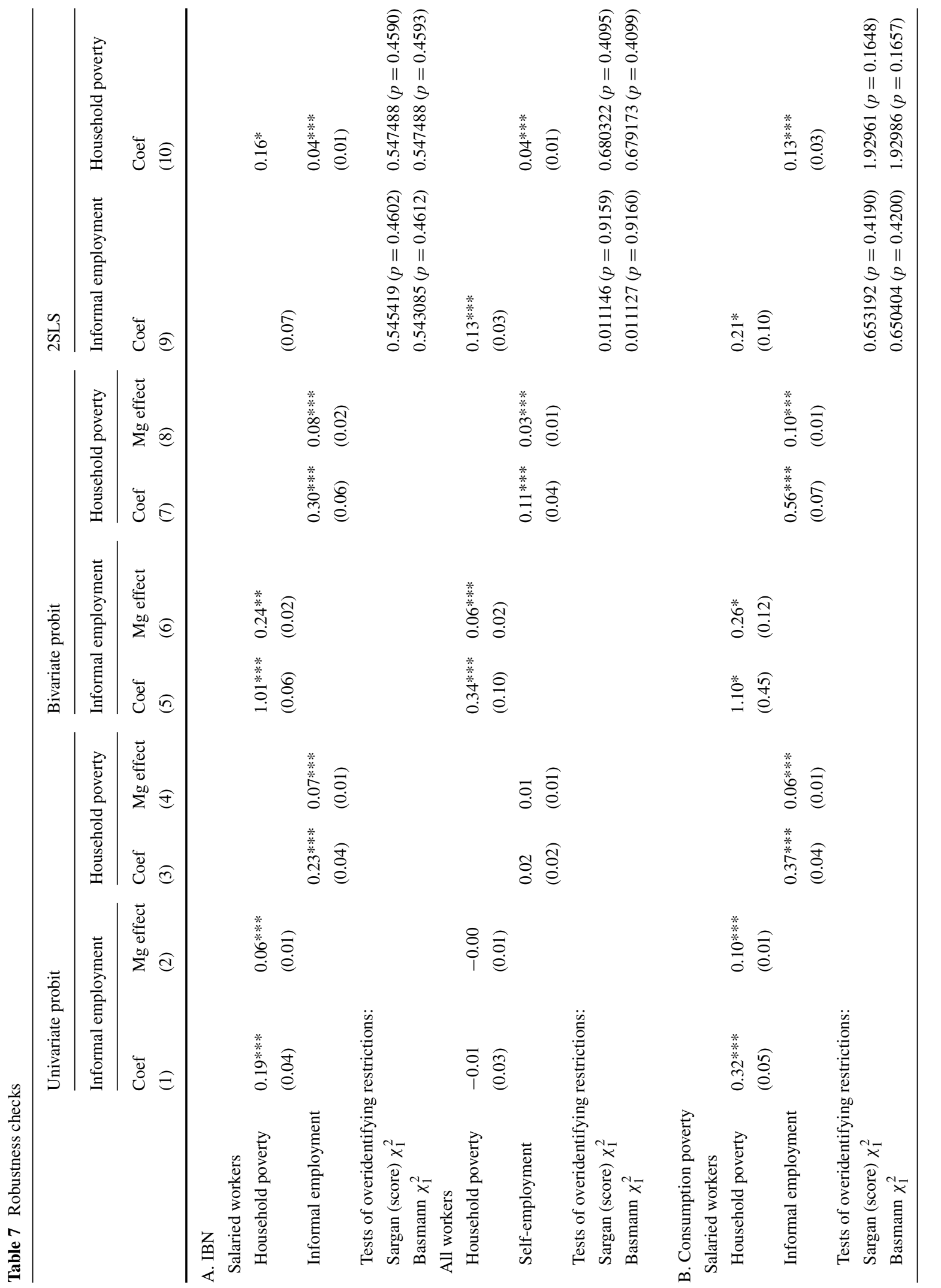




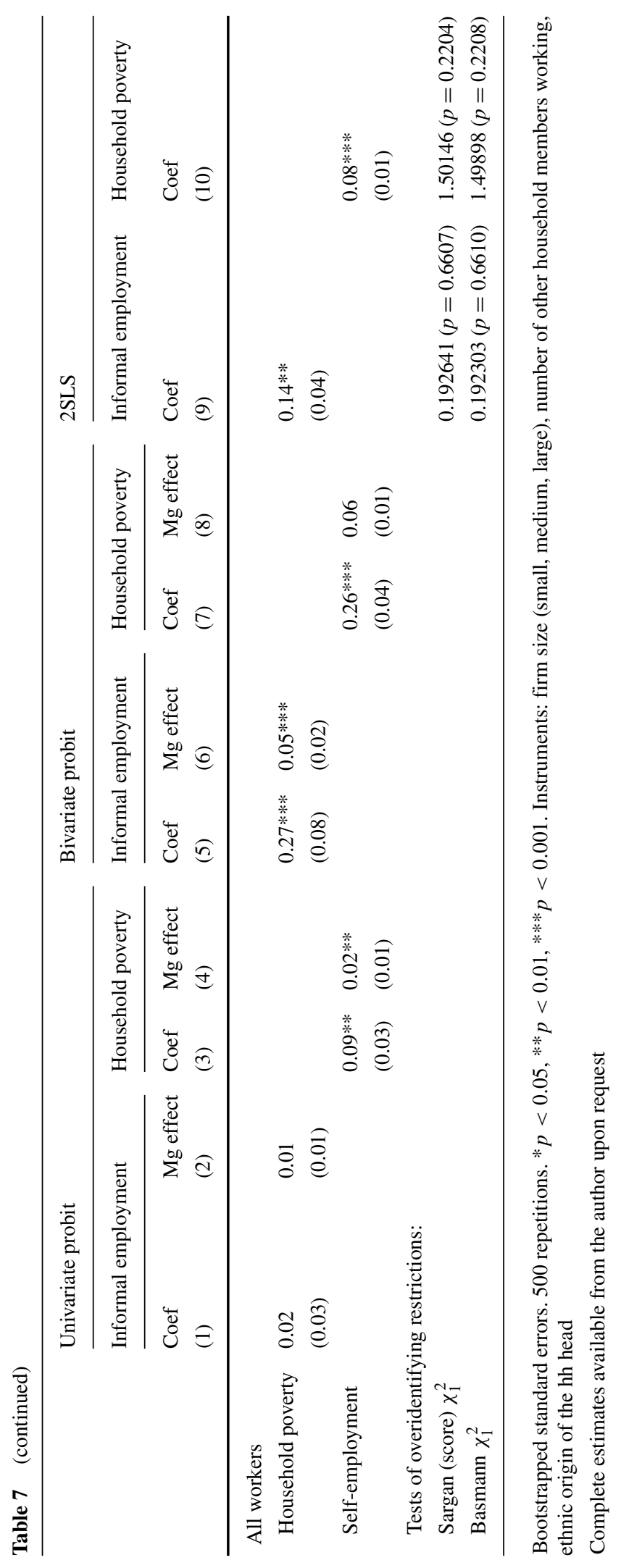


While the effects of informality on poverty are lower than the effects of poverty on informality, the results raise concerns about the implications of informal work (salaried or self-employment) for poverty. In particular, informal work, here defined as the lack of social security coverage, concerns more than $60 \%$ of the population under study. With a high percentage of low-skilled workers and with poverty rates being the highest among this group of workers, future implications of the lack of retirement benefits are worrisome.

These results suggest several broader implications and avenues for future research. For one, consistent with the literature on heterogeneous labor markets, these results show the relevance of diversity among informal workers in the country and speak to the need for public policies targeting different groups of workers. The findings further offer additional evidence on the relevance of education for decreasing poverty and its effect on informality. In particular, they show the need of incentives appealing to various levels of skills. In terms of future analysis, the findings highlight the need for studies looking at small-firm survival in Ecuador, as well as the role of remittances in alleviating liquidity constraints faced by entrepreneurs in the country.

\section{Conclusion}

This study uses microeconomic data from the Ecuadorian Family Expenditure survey of 2014 to study the determinants of poverty and informality in the country, taking into account the possible two-way relationship that exists between these two phenomena. The estimations confirm previous results in the literature that, despite controlling for many relevant variables, informality and poverty are correlated and so this double causality should be taken into account when studying these factors.

In Ecuador, as in many Latin American countries, a high proportion of informal employment is of poor quality. In general, informally employed workers are found to have a relatively low education level and low wages, which supports the idea that these workers have no choice but to work informally. However, the complexity of the informal sector supports the view of a heterogeneous informal market in which work in the informal sector is both a demand-led phenomenon and a voluntary and primarily supply-led form of employment. Informal work is both a last-resort option for low-skilled workers and a voluntary choice for better-educated and entrepreneurial workers.

From a policy perspective, since poverty and informality are interrelated, the results suggest that no public policy could effectively eliminate either of the two phenomena if nothing is also done to alleviate the other. It is clear, for instance, that poverty reduction could only be sustainable if more and better employment opportunities are created. For the vast majority of households in Ecuador, labor income is the main (if not the only) source of income. Thus, quality job creation through enterprise development, as well as investment in education and training, is of great importance.

Last but not least, policies aiming to increase fiscal revenues from the higher-paid segment of the informal sector (salary jobs or self-employment) should be designed in such a way that they also provide incentives for these workers to become formal workers. Since more than $50 \%$ of informal workers are concentrated in small firms, measures to increase the incentives of small enterprises to become formal should also be part of these reforms.

Acknowledgements The author would like to thank the Editor and two anonymous referees for their valuable comments and suggestions on previous versions of this paper.

This study has been prepared within the UNU-WIDER project on 'The growth-employment-poverty nexus in Latin America in the 2000s'. Part of this paper was written when the author was a Research Fellow at UNU-WIDER. A previous version of this article circulated as UNU-WIDER working paper.

\section{Compliance with Ethical Standards}

\section{Conflict of interest}

The author declares that she has no conflict of interest.

Open Access This article is distributed under the terms of the Creative Commons Attribution 3.0 IGO License (http://creativecommons.org/licenses/by/3.0/igo/), which permits unrestricted use, duplication, adaptation, distribution, and reproduction in any medium or format, as long as you give appropriate credit to the original author(s) and the source. In any reproduction of this article there should not be any suggestion that UNU-WIDER or this article endorse any specific organization or products. The use of the UNU-WIDER logo is not permitted. This notice should be preserved along with the article's original URL. 


\section{Appendix}

Table 8 Variables definition

\begin{tabular}{|c|c|}
\hline Variable & Definition \\
\hline Hh poverty & Dummy variable for poverty status of the hh $($ poor $=1)$ \\
\hline Informal employment & Dummy variable for informal employment of the hh head (informal $=1$ ) \\
\hline Monthly earnings & Household head's monthly earnings \\
\hline Remittances & Dummy variable for receiving remittances $($ yes $=1)$ \\
\hline Hh size & Number of persons in the household \\
\hline Number of hh members working & Number of other household members working \\
\hline Number of hh members working formally & Number of other household members with formal employment \\
\hline Living in couple & Dummy variable for married or couples living together \\
\hline Gender & Dummy variable for gender of the hh head $($ male $=1)$ \\
\hline Ethnic origin & Dummy variable for ethnic origin of the hh head (minority $=1$ ) \\
\hline Age & Household head's age in years \\
\hline \multicolumn{2}{|l|}{ Education } \\
\hline Without formal schooling & Dummy variable indicating no formal schooling \\
\hline Some primary & Dummy variable for some years of primary education \\
\hline Primary completed & Dummy variable for completed primary education \\
\hline Secondary & Dummy variable for some years of secondary education \\
\hline Secondary & Dummy variable for completed secondary education \\
\hline Post-secondary & Dummy variable for more than completed secondary education \\
\hline \multicolumn{2}{|l|}{ Area of residence } \\
\hline Urban & Dummy variable for urban residence \\
\hline North region & Dummy variable for northern region residence \\
\hline Coast region & Dummy variable for coastal region residence \\
\hline Central region & Dummy variable for central region residence \\
\hline South region & Dummy variable for southern region residence \\
\hline \multicolumn{2}{|l|}{ Labor market } \\
\hline Tenure & Years of tenure \\
\hline Small firm & Dummy variable if the firm has fewer than 10 workers \\
\hline Medium firm & Dummy variable if the firm has $10-49$ workers \\
\hline Large firm & Dummy variable if the firm has more than 50 workers \\
\hline Agriculture & Dummy variable for the agriculture and fishing industries \\
\hline Mining & Dummy variable for the mining industry \\
\hline Manufacturing & Dummy variable for the manufacturing industry \\
\hline Construction & Dummy variable for the construction industry \\
\hline Commerce and trade & Dummy variable for the commerce and trade related services industry \\
\hline Transportation & Dummy variable for the transportation and communications industries \\
\hline Services & Dummy variable for personal and social services industries \\
\hline Managers & Dummy variable for managers and directors \\
\hline Professionals & Dummy variable for professionals \\
\hline Technicians & Dummy variable for technicians \\
\hline Office workers & Dummy variable for office workers \\
\hline Service workers & Dummy variable for service workers \\
\hline
\end{tabular}


Table 8 (continued)

Skilled agricultural worker

Craft and related trades workers

Plant and machine operators

Elementary occupations workers
Dummy variable for skilled agricultural workers

Dummy variable for craft and related trades workers Dummy variable for plant and machine operators

Dummy variable for elementary occupations workers

\section{References}

Amuedo-Dorantes, C. (2004). Determinants and poverty implications of informal sector work in Chile. Economic Development and Cultural Change, 52(2), 347-368.

Angrist, J.D. (2001). Estimation of limited dependent variable models with dummy endogenous regressors: simple strategies for empirical practice. Journal of Business \& Economic Statistics, 19(1), 2-16.

Atal, J.P., Nopo, H., Winder, N. (2009). New century, old disparities: gender and ethnic wage gaps in Latin America. Working Paper 109, Inter-American Development Bank.

Canelas, C. (2014). Minimum wage and informality in Ecuador. Working Paper 2014/006, UNU-WIDER.

Canelas, C., \& Salazar, S. (2014). Gender and ethnic inequalities in LAC countries. IZA Journal of Labor \& Development, 3(1), 18.

Chaudhuri, S., \& Mukhopadhyay, U. (2010). Revisiting the informal sector: a general equilibrium approach. New York: Springer.

Cortés Aguilar, A., García Muñoz, T.M., Moro-Egido, A.I. (2013). Heterogeneous self-employment and satisfaction in Latin America. Journal of Economic Psychology, 39, 4461.

Cruces, G., Fields, G.S., Jaume, D., Viollaz, M. (2015). The growth-employment-poverty nexus in Latin America in the 2000s: Ecuador country study. Working Paper 76/2015, UNU-WIDER.

Cunningham, W., \& Maloney, W. (2001). Heterogeneity among Mexican microenterprise sector: an application of factor and cluster analysis. Economic Development and Cultural Change, 50(1), 131-156.

Devicienti, F., Groisman, F., Poggi, A. (2009). Informality and poverty: are these processes dynamically interrelated? Evidence from Argentina. Working Paper 146, ECINEQ.

Fields, G.S. (1975). Rural-urban migration, urban unemployment and underemployment, and job-search activity in LDCs. Journal of Development Economics, 2(2), 165-187.

Gasparini, L., \& Tornarolli, L. (2009). Labor informality in Latin America and the Caribbean: patterns and trends from household survey microdata. Desarrollo y Sociedad, 2009, 13-80.
Günther, I., \& Launov, A. (2012). Informal employment in developing countries: opportunity or last resort? Journal of Development Economics, 97(1), 88-98.

Harati, R. (2013). Heterogeneity in the Egyptian informal labour market: choice or obligation? Revue d'économie Politique 123(4), 623-639.

Harris, J.R., \& Todaro, M.P. (1970). Migration, unemployment \& development: a two-sector analysis. American Economic Review, 60(1), 126-142.

Heckman, J.J. (1978). Dummy endogenous variables in a simultaneous equation system. Econometrica, 46(4), 931-959.

ILO. (2014). Trends in informal employment in Ecuador: 2009 2012. Notes on formalization. Geneva: International Labour Organization.

Jacome, L. (2004). The late 1990s financial crisis in Ecuador: institutional weaknesses, fiscal rigidities, and financial dollarization at work. Working Paper 04/12, IMF.

Lewis, W.A. (1954). Economic development with unlimited supplies of labour. The Manchester School, 22(2), 139-191.

Loayza, N.V., Serven, L., Sugawara, N. (2009). Informality in Latin America and the Caribbean. Policy Research Working Paper 4888, World Bank.

Maddala, G. (1983). Limited-dependent and qualitative variables in econometrics. Cambridge: Cambridge University Press.

Mallar, C.D. (1977). The estimation of simultaneous probability models. Econometrica, 45(7), 1717-1722.

Maurizio, R. (2012). Labour informality in Latin America: the case of Argentina, Chile, Brazil and Peru. Working Paper 165, Brooks World Poverty Institute.

Nazier, H., \& Ramadan, R. (2015). Informality and poverty: a causality dilemma with application to Egypt. Advances in Management and Applied Economics, 5(4), 1-4.

Paulson, A., \& Townsend, R. (2005). Financial constraints and entrepreneurship: evidence from the Thai financial crisis. Economic Perspectives, 29(3), 34-48.

Webster, C., Wu, F., Zhang, F., Sarkar, C. (2016). Informality, property rights, and poverty in China's 'Favelas'. World Development, 78, 461-476.

World Bank. (2012). Ecuador: the faces of informality. Washington, DC: World Bank.

World Bank. (2013). World Development Report 2013: Jobs. Washington, DC: World Bank. 